\title{
Silent Political Apathy in Urban Society: The Case of Medan 2018 Election
}

\author{
Derajad Sulistyo Widhyharto ${ }^{1}$, Desi Rahmawati ${ }^{2}$, \\ Norin Mustika Rahadiri Abheseka ${ }^{3}$ \\ ${ }^{1}$ Departemen of Sosiology, Faculty of Social and Political Sciences, Universitas Gadjah Mada \\ (email: derajad@ugm.ac.id) \\ ${ }^{2}$ Research Centre for Politics and Government (PolGov), Faculty of Social and Political Sciences, \\ Universitas Gadjah Mada (email: desirahma2@ugm.ac.id) \\ ${ }^{3}$ Research Centre for Politics and Government (PolGov), Faculty of Social and Political Sciences, \\ Universitas Gadjah Mada (email: rabheseka@gmail.com)
}

\begin{abstract}
Studies on non-voting behavior and which depart from social perspectives have long been stagnated due to the dominance of analysis that puts systems, institutionalization, political mechanisms and participation as the main viewpoints of the studies. This study using social perspectives is useful to explain why voters were not present at polling stations during the Medan 2018 Election. It elaborates the social aspects that influenced non-voting behavior in the urban area of Medan in North Sumatra, Indonesia during the 2018 gubernatorial election. Utilizing mixmethod strategies, instead of citing social aspects as a mere research context, this article argues that social aspects in the form of social cleavages worked behind the silent apathy, namely apathy that was implicitly indicated by voters who were not present at polling stations. Social cleavages including ethnicity, religion and gender indicated a paradox since they-with the exception of gender-were used by candidates as the main campaign substance. On the other hand, large numbers of people showed disinterest in these social cleavages during the election. This article explains why abstained voters hid their disinterest behind their excuses for not being present at the polling stations for economic (working activities) and other reasons.
\end{abstract}

\section{Keywords:}

apathy; election; non-voting behavior; social cleavage; voter abstention

\section{Introduction}

The sociological perspective has rarely been used to analyze non-voting behavior rather than the political science approach. If the latter is very productive in yielding studies about the system and institutionalization of elections (i.e., Blais \& Aarts, 2006; Delwit, 2013; Kang, 2004; Power \& Roberts, 1995), non-supportive electoral mechanisms and institutions (i.e., lima 1990 in Power \& Roberts, 1995), alienation of candidates (Adams, Dow, \& Merrill, 2006), and technicalities of electoral administration (Downs, 1957; Freixas \&
Zwicker, 2003), studies that depart from a social perspective experience stagnation.

This stagnation is in line with the strengthening of behavioral approaches that prioritize voter rationality (i.e., Delwit, 2013) and political culture which prioritize welfare rather than class mobility (Achterberg, 2006). The use of social perspective is more associated with studies on non-economic factors such as the strengthening levels of education and technocraticism that affect changes in social cleavage structure (Jansen, De Graaf, \& Need, 2011). Also, studies on social obligations, social 
pressure $^{1}$ and low motivation for "social act" 2 (Sternheimer, 2012) rather than social cleavage and its implications for voting behavior. Hence, social class, religion, regional identity and ethnicity that were previously formed the constellation of political parties are no longer known as the main antecedents that greatly influence the decision to vote (Elff, 2007).

Evans (2004) on the other hand, reminds the relationship between social studies and voting behavior when she identified two kinds of study, namely the political sociology explanation and the sociology of political explanation. If the first one discusses the mobilization based on social cleavages, the second one discusses the social cleavages' influence on voting behavior. The social cleavages include religion, ethnicity and gender.

This article follows the second perspective in explaining a number of social indications that arise from previous research. Study about the 2018 gubernatorial election in Medan North Sumatra Indonesia that the authors were involved explored explicit aspects as explanation for voter absence in polling stations. The survey stage found that economic activity was the main reason for voter abstention while the qualitative discussion elaborated more on technical and administrative aspects of the election. (Budi, et.al., 2018; 2020 upcoming). Some social indications such as religion, ethnicity, and gender stand out but have not been discussed as social aspects that affect voter abstention.

Instead of revising findings from previous research, this article intends to take a different point of view. Voter abstention is identified as political apathy, referring to the classic definition that places any activity absent from polling stations as political apathy (Rosenberg,

\footnotetext{
1 See for example https://www.mtholyoke. edu/ hkwarner/PublicFinancePage10.html

2 A sense of being involved in the community while attending the polling stations.
}

1956; Dean, 1965). The term "silent" is placed as an adjective to indicate the implicit tone or level of apathy, meanwhile social cleavages are placed as social aspects that influence political apathy as Evans indicated in her study (2004).

This article intends to answer the question of: how do those social indicators affect political apathy? This article argues that social cleavages influence silent apathy. Ethnic, religious, and gender worked as social cleavages in which members respond to the social and political situations by deciding not to vote, without necessarily directly linking it to ideological reasons. Social cleavages also revealed a paradox because in the midst of the trend of candidates using ethnic, religious and gender issues as campaign material, voters who came from the three cleavages actually showed silent apathy.

As indicated earlier, this article utilizes data on Voters Abstention in the 2018 Medan gubernatorial election (Budi et.al., 2018). Medan, the metropolitan city in North Sumatra Indonesia has been acknowledged as the city with the highest level of abstention. Between 2000 and 2018, the voter abstention was ranged from 36.62 to $74.62 \%$. In 2018, despite its dramatically reduced to $41.62 \%$, Medan still maintains its image as an area with high abstention $^{3}$. The social background is not only characterized by their economic profile, but also social groupings based on religion, ethnicity and gender, which in the 2018 elections indicate certain trends.

This article analyzes surveys as well as qualitative data about abstained voters with further investigation that includes the contribution of social indicators. Hence, this paper considers interview results including those with the head and members of KPU (General Elections Commissions) in Medan and North Sumatra, Bawaslu (Election Supervisory

\footnotetext{
3 The average abstention in Indonesia is usually below $40 \%$.
} 
Body) in Medan, electoral technical officers, political parties, academics, local journalists, and activists. This paper also includes official election documents, government statistics, and media news as data sources.

\section{Social Cleavage and Silent Political Apathy}

Political apathy is a global phenomenon whose emergence tends to strengthen from time to time (Fieldhouse, Tranmer, \& Russell, 2007; Henn, Weinstein, \& Forrest, 2005). Scholars tend to define political apathy through narrow and concise definitions, sometimes indicating different perspectives. Classical research indicates that "political apathy, or its converse, political participation, has generally been defined simply as voting or non-voting." Political apathy arises because of indifference related to powerlessness (Dean, 1965). The absence of political interest and activity can be determined by many reasons, including "social restraints, feelings of futility, and the absence of spurs to action all tended to inhibit participation in the democratic process" (Rosenberg, 1954: 349).

DeLuca (1995) refers to C. Wright Mills and Herbert Marcuse, on the other hand, saying that political apathy is related to the loss of political space that causes alienation. It does not necessarily indicate public apathy towards the political process (Martin, 2012) and many of those who are apathetic to electoral politics are actually involved in activities such as volunteering, demonstrations and petitions (Dalton, 2010). However, it is very common that political apathy causes the non-voting behavior or voter abstention ( Carlin 2006 in Runciman, 2016).

Although many do not associate political apathy with ideology, some others attribute this to ideological expressions that come from "dislike of politicians, lack of variety among candidates, lack of trust in government, and negative media coverage of subjects involved in politics" (Windber, 2020) or ideological opposition (Budi et al., 2018). In the midst of various definitions indicating different levels or ranges of political apathy, this article puts political apathy simply as the non-voting behavior which is indicated through the absence of voters at the polling stations. The term of silent apathy may rarely be found in existing studies but this article appears to show the tone or level of apathy, which in this case study appears not explicitly but is indicated through several sociological indicators.

This article follows a structuralist line of thinking that indicates a link between social cleavage and voting behavior. Evans (2004) identified two explanatory trends, namely the political sociology explanation and the sociology of political explanation. The first trend, which is political sociology explanation, mainly puts Lipset \& Rokkan's study (1967) as the most influential writing. They indicate that social divisions such as ethnicity, religion, and the development of the post-industrial revolution produces social and political divisions. If education and materialistic oriented working class produce cleavages based on center-periphery, rural-urban, church-state, and class, and worker-owner (Pierides, 2009), cleavages affects individual's party choice and provide opportunities for political elites to mobilize voting (Evans, 2004).

In Indonesian current politics, social cleavages are more prominent compared to secularism (Higashikata \& Kawamura, 2015). Classical studies have shown that cleavages in the form of ethnicity and religion underlined the constellation of political parties in Indonesian 1950's election (Feith, 2007; 1963). Feith's statement regarding political streams (politik aliran) even became an influential argument in political science studies until now. In the 2018 Gubernatorial election in Medan, this issue still arises as an explanation for the preferences of first-time voters to vote (Damanik, 2018a). Previously in 2017 during the Jakarta Gubernatorial Election, studies 
also indicate that religious cleavage worked stronger compared to socio-economic factors, even becoming the basis for voting behavior (Panggabean, 2017).

Ethnic divisions and beliefs are suspected to fill the dimensions of voters' religio-political identity which strengthens along with the weakening of the political party function (Trihartono \& Patriadi, 2016). Gender, that globally "has never been a clear-cut cleavage determining electoral choice" (Abendschon \& Steinmetz, 2014; Inglehart \& Norris, 2000) started to get attention as soon as there is a shift in the trend in research. Female voter behavior associated with conservatism, religious belief, and secularism (Abendschøn \& Steinmetz, 2014) indicates gender gap of development that affects their participation in elections ${ }^{4}$ thus contribute to analysis that links election with socio-structural and situational aspects ${ }^{5}$ (McClurg, Wade, \& Philips, 2012).

Evans' (2004: 43-90) second identification of trend, which is the sociology of political explanation, does not place cleavage-based political mobilization as the center of discussion. She puts her attention on Sartori's famous writing in the 1960s and studies of Columbia school which mentioned a number of social indicators as social cleavages including gender, religion, and ethnicity as important aspects that influence voting. These social indicators work on the basis of differentiation which is characterized by shared characteristics and interests, intergenerational transmission of values, and contacts characterized by long individual membership in a social community. This article therefore uses Evan's second categorization, the sociology of political explanation, as a general guide for the analysis.

\footnotetext{
4 Women who work and are economically independent have higher levels of participation and exposure to feminist ideas than men (Jelen, Thomas, \& Wilcox, 1994) (Jelen et al., 1994)

5 This includes women's and men's role in work, family and society.
}

To elaborate social aspects, this article reflects the perspective of Evans (2004), who sees voting as a unique activity related to the role of all eligible voters. She indicates that voters' decisions are influenced by various social considerations related to their positions in the social structure. Therefore, a vote usually reflects any element of the social structure that may affect the voter.

Evans (2004 p. 43) provides four bases of analysis to examine the relationship between social structure and voting behavior. First, the social context in which a person grows may influence their political choices since the series of beliefs, values, culture and actions are inherent in a person through the process of internalization and socialization. Second, members of the group usually face various distinguishing categories. These include age, gender, education level, economic level, occupation and so on. The joining of someone in a group causes them to feel the same experiences and interactions in the same group. Through this description, everyone from the same group will develop a common trait because of the same process of development and experience. Third, political parties tend to target specific social groups in the community to mobilize support (votes). They very likely attract support through their common view over a community group since it is impossible to satisfy everyone's interests. Fourth, in order to mobilize this large group of voters, a party is like playing a gambling. It means that one party's benefits are the other party's loss and vice versa.

\section{Explaining Voter Abstention through Mixed- method Analysis}

Mixed-method strategy which is manifested in the form of combining quantitative and qualitative methods is referring to dynamic interconnections among factors (see for example Hesse-Biber, 2010). The advantage of this method is the possibility to cross-check the 
overlapping aspects of a phenomenon (Greene, et.al., 1989 in Hesse-Biber, 2010; Onwuegbuzie \& Collins, 2007). Therefore, data analysis applies a combined technique, including demographic data, surveys and observations, and social mapping.

This research utilizes complementarity as a type of methodological design. Hence, the relation between quantitative and qualitative approaches is cross-validation. Technically, the sampling is conducted through a multilevel strategy with different levels of respondent/ informant to enrich the explanation dimension. The selection of sample also refers to the research objective of answering questions with a richer perspective (Onwuegbuzie \& Collins, 2007). This means that the sample of respondents/informants in the quantitative and qualitative phases is different in consideration of filling the same dimensions that are related with the investigated issue.

In the quantitative phase, the survey was conducted using a multi-stage stratified random sampling involving 400 respondents spread across 21 sub districts (kecamatan) in Medan. They were voters from the Final Voter List (DPT) who were identified as not present at the polling stations (TPS). In this case, data access from the Election Commission (KPU) was crucial since it allowed researchers to obtain information about abstained voters. Random sampling was carried out at forty polling stations where ten respondents were each taken. This data collection also applied the principle of proportional gender where male and female respondents were targeted in the same composition.

Meanwhile, the qualitative phase applied a non-random sampling strategy. This was conducted through targeted interviews and focus group discussions (FGD). In this phase, quantitative enumerators, some members of the City Election Commission (KPU Medan), the Subdistrict Election Committee (PPK), the voting committee (PPS), the "success team" of candidates, NGO activists and academics involved in the process.

\section{The Context, Main Findings, and the Indication for Further Analysis}

Medan, the capital city of North Sumatra is the biggest metropolitan city in the northern part of the island. Built around the end of the 18 th century by the Dutch Colonial ruler, Medan was the main location for plantation business and the trading of estate crops commodities (Reid, 2014; Stoler, 2005). The $265.1 \mathrm{~km}^{2}$ city now plays an important role as a trading city in the Malacca Strait. This has implications for at least two things, namely the composition of a heterogeneous population (see Damanik, 2018b) and the economic structure characterized by services and manufacturing business.

The consistent migration from the beginning to the present resulted in ethnic diversity. Here, the Javanese descent dominates the population quantitatively and Batak (and its sub-ethnics) - the indigenous ones--have been politically important since many strong politicians in Medan and Jakarta are members of this tribe. Beside them, Medan is also known by Chinese, Tamil/Indian, and Arabic descent migrants. Their presence strengthens the city's profile as a business area with unique configuration of ethnics. Medan is even known as the largest distribution area for Javanese, Chinese, Tamil/Indian, and Arabic descendants of migrants in Indonesia.

In the midst of ethnic heterogeneity, the issue of social cleavage surrounds the Chinese descent and Batak populations. For several centuries, the Chinese-descents have occupied residential areas where no other ethnic groups lived in the same location (Christie, 2013). In addition to their domination upon the economic sector, the use of Hokkien Chinese rather than Bahasa in their daily lives and their settlement patterns raised the stereotype of exclusive citizens (Faraidiany, 2016) ${ }^{6}$. This pattern of

${ }_{6}$ Also being explained by Thomas Hutoyo (pseudonym), 
Table 1.

Ethnic Composition and Distribution in 2004

\begin{tabular}{rlrl}
\hline No. & \multicolumn{1}{c}{ Tribe } & Percentage & \multicolumn{1}{c}{ Kecamatan (Main District of Distribution) } \\
\hline 1 & Java & $12,85-59,42$ & Medan Deli, Medan Marelan, Medan Polonia \\
2 & Malay & $2,22-23,65$ & Medan Labuhan, Medan Marelan, Medan Belawan \\
3 & Tapanuli/Toba* & $5,31-26,78$ & Medan Kota, Medan Denai, Medan Helvetia \\
4 & Chinese descent & $0,2-29,94$ & Medan Area, Medan Kota, Medan Maimun, Medan Petisah, Medan \\
& & Barat \\
5 & South Tapanuli/Madina & $4,48-24,36$ & Medan Tembung, Medan Barat, Medan Timur, Medan Amplas \\
6 & Karo* $_{7}^{*}$ Simalungun* & $0,64-32,5$ & Medan Baru, Medan Selayang, Medan Tuntungan \\
8 & Pakpak/Dairi* & $0,63-3,28$ & Medan Selayang dan Medan Tuntungan \\
9 & Nias & $0,2-2,48$ & Medan Johor, Medan Tuntungan \\
10 & Coastal/Middle Tapanuli* & $0,18-1,82$ & Medan Tuntungan, Medan Johor, Medan Amplas \\
11 & Minangkabau & $2,77-30,93$ & Medan Barat, Medan Belawan, Medan Johor \\
12 & Tamil/India & $0,09-6,27$ & Medan Polonia, Medan Petisah, Medan Baru \\
13 & Arab & $0,20-0,35$ & Medan Area, Medan Timur, Medan Perjuangan \\
\hline \multicolumn{2}{c}{ Total } & $100,00 \%$ & \\
\hline
\end{tabular}

Source: BPS Kota Medan 2004 in Mukmin E Damanik (2018). *Batak Sub-tribe

residents is reminiscent of the distribution of the Batak and its sub-tribes that is divided into ecological and religious boundaries. Where, the distribution of their population as mountainous and coastal communities shows the spread of non-Muslim and Muslim religions in North Sumatra ${ }^{7}$.

However, in contrast to the Batak, the issue of exclusivity of Chinese descendants resulted in serious problems in 1998. Then, the non-Chinese residents were considered as conducting social unrest to the Chinesedescendants. The riot caused significant economic, social and political losses to the attacked community. However, stereotypes upon this community as migrants with their own way of life declined along with the revitalization of their role in national and local politics. The evidence of their involvement in politics can be traced from their involvement in legislative elections both at national and local level (Faraidiany, 2016).

With the cleavage tendency, this issue of ethnic cleavage does not appear to be the

the Chinese descent resident in Medan, June 2018

7 Interviews with two academicians for The North Sumatra University, June 2018 main social problem nowadays despite its effect on abstention as will be discussed later. Politically, the issue of ethnicity during the 2018 gubernatorial election appeared more on the Javanese and Batak issues that transcended spatial barriers. This issue also competed with other identity issues such as politicization of religion. Thomas (1988) explains that most Muslims in Medan received a militantly orthodox religious teaching. With population reaching 65 percent Muslim of the total population (BPS 2018) and the strengthening of identity politics, politicization of religious became relevant to Medan.

Hence, the two governor candidates appeared to be aiming for identity issues in different ways. The first pair of candidates, Edy Rahmayadi and Musa Rajekshah, seemed to bring their profiles closer to the Muslims. Therefore, their profile as non-indigenous was less important. Their use of religious strategy involved designing campaigns which were combined with religious events. They even utilized the largest Islamic religious institution (MUI) and controversial clerics to support their winning agenda. Rahmayadi's profile as a military general and Rajekshah's profile as 
a businessman with a background of Pemuda Pancasila - a mass organization established by the New Order $^{8}$ - were then managed to strengthen the candidates' masculine character which was important for voters9.

The second pair of candidates, Djarot Saiful Hidayat and Sihar Sitorus highlighted the issue of Javanese and Batak ethnicity to attract voters. Hidayat, the former Governor of Jakarta who took the position after Ahok's controversial imprisonment in $2017^{10}$, appeared to approach the largest ethnic voter group, which was the population of Javanese descents. With a weak connectivity with the voters-even those of Javanese descent-Hidayat unwisely chose a local politician with a minority religious background. Sitorus, the young entrepreneur, highlighted his profile as a Catholic Batak. Highlights on ethnic profiles amid the tendency to politicization of religion made it difficult for them to win the election. Rahmayadi and Rajekshah eventually won the battle with $57.57 \%$ at the North Sumatra level, and more than $60 \%$ at Medan.

Concerning the economic structure, Medan relies on the service sector. The contribution of these sectors to the gross regional domestic income reaches about $42 \%$ of total revenue ${ }^{11}$. The strength of this sector, compared to manufacturing

\footnotetext{
8 Pemuda Pancasila is a youth organization formed by the New Order regime. Being one of the state corporatist institutions, this organization has long been known for its image as a gangster organization that supported authoritarian government. At the end of the New Order era in 1998, they devoted a "considerable effort to correct the impression" by claiming to be an organization that "vows to defend Pancasila and the 1945 Constitution" (Ryter, 2001). After 1998, this organization still exists especially in regions. They often take the role as important political supporters for local head candidates as, for example, seen in the 2014 gubernatorial election in North Sumatra (Amin, 2014).

9 Despite its character as a metropolitan city, Medan keeps aspects of locality which include the voters' imagination about the personality of masculine leader. Interview with Walid, campaign team spokesman, July 2018.

${ }^{10}$ Ahok or Basuki Cahaya Purnama was defeated and his case became an evidence about strong identity politics in Jakarta, even Indonesia.

${ }^{11}$ At current prices (BPS, 2018, pp. 45-6).
}

and agriculture, was also evident for the type of employed population. Government statistical data showed that $97 \%$ of the labor force totaling 972,274 worked in the service sector (BPS, 2018) ${ }^{12}$.

However, beside the working category, Medan also faced residents in the productive age who were not economically active. This group of 594,983 people included students (32\%), housekeeping (54\%) and others (13\%). Interestingly, in terms of gender, the total population of those who were economically inactive was largely women. Where, their number reaches $68 \%$ of the total of non-labor force (BPS, 2018). There were many factors that caused women to be in economically nonproductive sectors, including employment and culture. However, in terms of education level, women were not far left behind. Most of them graduated from high school. Their numbers were also superior to men at certain educational levels, namely at Diploma I / II / III / Academy levels. This indicated that in terms of gender most women in Medan had a good level of education. Hence, the issue of abstention due to weak literacy can hardly be pinned on women (BPS, 2018).

Identification of the economic structure and employment is important because the general findings of voter behavior in this city show that working activity was the main reason for abstention in the 2018 gubernatorial election.

The table above shows interesting data as there were quite a lot of respondents who did not put their answers into the table of reasons. A total of $22.19 \%$ of respondents chose another answer and $11.22 \%$ chose not to answer this question. Beyond that, skepticism about the election also seemed to characterize the results. This is for example indicated by the answer that the election will not have an impact on their life (13.01\%). The above results are interesting when juxtaposed with the findings from the qualitative stages as follows.

\footnotetext{
${ }^{12}$ Total population was 2.247.425 (BPS, 2018).
} 
Table 2.

Reasons for Voter Abstention

\begin{tabular}{lc}
\hline \multicolumn{1}{c}{ Reasons for Non-voting/Not Coming to the Poll Station } & Percentage (\%) \\
\hline Being influenced by family/close relatives & 3.57 \\
Being influenced by neighborhood/neighbors & 2.30 \\
Election will not change/give any impact on life & 13.01 \\
Do not know the candidate & 5.36 \\
Busy with working activity & 34.18 \\
Not registered as voter/ other administrative obstacles & 7.91 \\
Beliefs/ religious beliefs & 0.26 \\
Others & 22.19 \\
Do not know/ do not answer the question & 11.22 \\
\hline
\end{tabular}

Source: Budi et.al, 2018

Table 3.

Cross Tabulation on the question "Why did you not come to the polling station?"

\begin{tabular}{|c|c|c|c|c|c|c|c|c|c|c|c|}
\hline \multirow{2}{*}{$\begin{array}{l}\text { Respondent Based on } \\
\text { Employment/Activity }\end{array}$} & \multicolumn{11}{|c|}{ The Reasons for Non-voting } \\
\hline & $(1)^{*}$ & $(2)^{*}$ & $(3)^{*}$ & $(4)^{*}$ & $(5)^{*}$ & $(6)^{*}$ & $(7)^{*}$ & $(8)^{*}$ & $(9)^{*}$ & Total & Percent \\
\hline Labor & 2 & 2 & 7 & 1 & 12 & 1 & 1 & 1 & 3 & 30 & 8 \\
\hline Teacher/lecturer & 0 & 1 & 1 & 0 & 0 & 0 & 0 & 2 & 2 & 6 & 2 \\
\hline Housewife & 5 & 1 & 12 & 3 & 14 & 8 & 0 & 24 & 9 & 76 & 19 \\
\hline Student & 1 & 0 & 4 & 3 & 11 & 8 & 0 & 13 & 9 & 49 & 13 \\
\hline Fisherman & 1 & 0 & 1 & 1 & 2 & 0 & 0 & 1 & 0 & 6 & 2 \\
\hline Small trader & 1 & 1 & 4 & 2 & 13 & 2 & 0 & 4 & 5 & 32 & 8 \\
\hline Civil servant & 0 & 0 & 0 & 0 & 1 & 0 & 0 & 1 & 0 & 2 & 1 \\
\hline Private employees & 0 & 0 & 11 & 0 & 42 & 1 & 0 & 14 & 9 & 77 & 20 \\
\hline Businessman & 2 & 0 & 2 & 4 & 8 & 0 & 0 & 3 & 0 & 19 & 5 \\
\hline Retired & 0 & 0 & 2 & 1 & 0 & 0 & 0 & 6 & 1 & 10 & 3 \\
\hline Farmer & 0 & 2 & 0 & 0 & 4 & 0 & 0 & 0 & 0 & 6 & 2 \\
\hline Professional & 0 & 0 & 0 & 0 & 2 & 0 & 0 & 0 & 0 & 2 & 1 \\
\hline Seeking employment & 0 & 0 & 2 & 2 & 3 & 4 & 0 & 5 & 4 & 20 & 5 \\
\hline Entrepreneur & 0 & 0 & 3 & 1 & 12 & 5 & 0 & 9 & 1 & 31 & 8 \\
\hline \multirow{2}{*}{$\begin{array}{l}\text { Do not know/do not } \\
\text { answer the question }\end{array}$} & 2 & 2 & 2 & 3 & 10 & 2 & 0 & 4 & 1 & 26 & 7 \\
\hline & 14 & 9 & 51 & 21 & 134 & 31 & 1 & 87 & 44 & 392 & 100 \\
\hline Percent & 4 & 2 & 13 & 5 & 34 & 8 & 0 & 22 & 11 & 100 & \\
\hline
\end{tabular}

Note: (1) Being influenced by family/close relatives; (2) Being influenced by neighborhood/ neighbors; (3) Election will not change/give any impact on life; (4) Do not know the candidate; (5) Busy with working activity; (6) Not registered as voter/ other administrative obstacles;

(7) Beliefs/ religious beliefs; (8) Others; (9) Do not know/ do not answer the question.

Source: Budi et.al. (2018)

\section{Discussion: The Indication of Social Cleavage and Silent Apathy in Voter Abstention}

The cross tabulation analysis that combines the answers of the question about "the reasons for non-voting" and the "type of respondent's employment" showed that the top three respondents with the answer of "busy with working activity" were private employees (31\$), housewives (10\%) and small traders $(10 \%)$. The high percentage of private employees who claimed to prioritize working activities indicated that some economic activities still operated during the polling day that was designated as a holiday ${ }^{13}$. Looking

\footnotetext{
${ }^{13}$ The Government of Indonesia designates polling day
} 
at the character of work, the private sector was likely to be an informal service sector which, among others, was demonstrated by active online taxi fleets on polling day. Meanwhile the existence of respondents with household activities and small traders were also interesting. These groups of employment could easily be associated as those with flexible activities, where the members have more flexible time to come at the polling stations. However, they decided not to go thus not vote in the election. Similarly, things were shown by the group of respondents with self-employed work (entrepreneur).

Is the reason: "busy with working activities" the final answer to abstained behavior? Beyond the main answer, the survey pointed to other aspects that silently contribute to people's choices to prioritize jobs or economic activities rather than giving their votes. Their answer to the question of "level of satisfaction with the provincial government" indicated that most of the respondents were dissatisfied with the performance of the provincial government. Table 6 shows that the total answer for "very dissatisfied" and "dissatisfied" reached 53\%, meanwhile those who "satisfied" and "very satisfied" with the provincial government reached $37 \%$.

\section{Table 4.}

Level of Satisfaction with the Provincial Government

\begin{tabular}{lc}
\hline Level of Satisfaction & Percent (\%) \\
\hline Very dissatisfied & 5 \\
Dissatisfied & 48 \\
Satisfied & 36 \\
Very satisfied & 1 \\
Invalid & 1 \\
Do not know / Do not answer the & 10 \\
question & 100 \\
\hline
\end{tabular}

Source: Budi et.al. (2018)

as a holiday to encourage participation.
As the survey did not trace further about the source of dissatisfaction, the qualitative phase of the study even found out that one of the causes for dissatisfaction was related to the government's slow response for the roadwork on one hand, but rampant corruption on the other hand ${ }^{14}$. North Sumatra was considered as one of the most corrupt regions in Indonesia. The Corruption Eradication Commission put the province as a red zone as indicator for severe corruption. In 2015, Governor Gatot Pujo Nugroho and his wife were arrested and charged with corruption. The case also ensnared several parliament members for their involvement in the conspiracy. In 2018, 38 members and former members of the provincial parliament who worked for the 20092014 and 2014-2019 periods were also charged with corruption ${ }^{15}$. Those cases indicate that the local political situation potentially contributed to the people's reluctance to vote. Hence, the Medan case even shows that a voter's decision to prioritize work does not merely reflect the work ethic of urban society. However, this was also influenced by their dissatisfaction with the government's performance. Checking these three aspects results in allegations of soft apathy or disregard for elections as explained below.

\section{Social Cleavage and Silent Apathy in Gender Aspect}

In terms of gender, the number of abstained voters in each sub-district studied was equal between men and women. This condition represented the situation in all districts where the percentage of abstention between the two genders was nearly equal. Both half of them were considered as being abstained. However, the level of abstention of women was slightly lower than men, thus

\footnotetext{
${ }^{14}$ As mentioned by some taxi drivers during the research, June 2018

${ }^{15}$ At least two former mayors and one former vice mayor of Medan were also arrested and charged with corruption. https://regional.kompas.com/ $\mathrm{read} / 2018 / 07 / 19 / 08421331 / 9$-kepala-daerah-disumatera-utara-yang-terjerat-korupsi?page=all
} 
indicated that gender cleavage appeared in Medan.

Table 5.

\begin{tabular}{clcc}
\multicolumn{2}{c}{$\begin{array}{c}\text { Comparison of } \begin{array}{c}\text { Abstention Rates from } \\
\text { the Gender Perspective }\end{array} \\
\text { No }\end{array}$} & \multicolumn{2}{c}{$\begin{array}{c}\text { Non-Voter/ Abstention } \\
\text { (Percent) }\end{array}$} \\
\cline { 3 - 4 } No & Subdistrict & Male & Female \\
\hline 1 & Medan Selayang & 53 & 47 \\
2 & Medan Timur & 53 & 47 \\
3 & Medan Petisah & 53 & 47 \\
4 & Medan Perjuangan & 53 & 47 \\
5 & Medan Polonia & 53 & 47 \\
6 & Medan Baru & 55 & 45 \\
7 & Medan Maimun & 53 & 47 \\
8 & Medan Tembung & 53 & 47 \\
9 & Medan Labuhan & 53 & 47 \\
10 & Medan Marelan & 52 & 48 \\
11 & Medan Johor & 53 & 47 \\
12 & Medan Area & 52 & 48 \\
13 & Medan Amplas & 53 & 47 \\
14 & Medan Belawan & 55 & 45 \\
15 & Medan Tuntungan & 54 & 46 \\
16 & Medan Deli & 52 & 48 \\
17 & Medan Barat & 54 & 46 \\
18 & Medan Denai & 53 & 47 \\
19 & Medan Helvetia & 54 & 46 \\
20 & Medan Sunggal & 53 & 47 \\
21 & Medan Kota & 53 & 47 \\
\hline
\end{tabular}

Source: KPU Medan 2018 database.
The table indicated that women voters could possibly build more active voter sentiment, thus strengthening the general assumption about gender and voting behavior. However, in terms of abstention, women also showed a tendency of reasons that were nearly similar to men. Where, the composition of reasons for abstention was evenly distributed across all possibilities of answers with the exception in two cases. First, both women and men chose "busy with working activities" as the main answer. Secondly, more female respondents hid their true reasons by choosing either "Other reason" or "Do not know/did not answer the question" (Figure 1).

Furthermore, an analysis of gender became more interesting when it was associated with the results of cross tabulations between "types of work" and "reasons for abstention" (Table 3). In this table, many women who answered "busy with working activities" were housewives. This group of women working in the domestic area was also noted as the largest group that hides reasons by answering "Other" or not answering the questions. This indicates women's disinterest or even skepticism towards the gubernatorial election-

\section{Figure 1.}

\section{Variation of Reasons for Abstention Based on Gender}

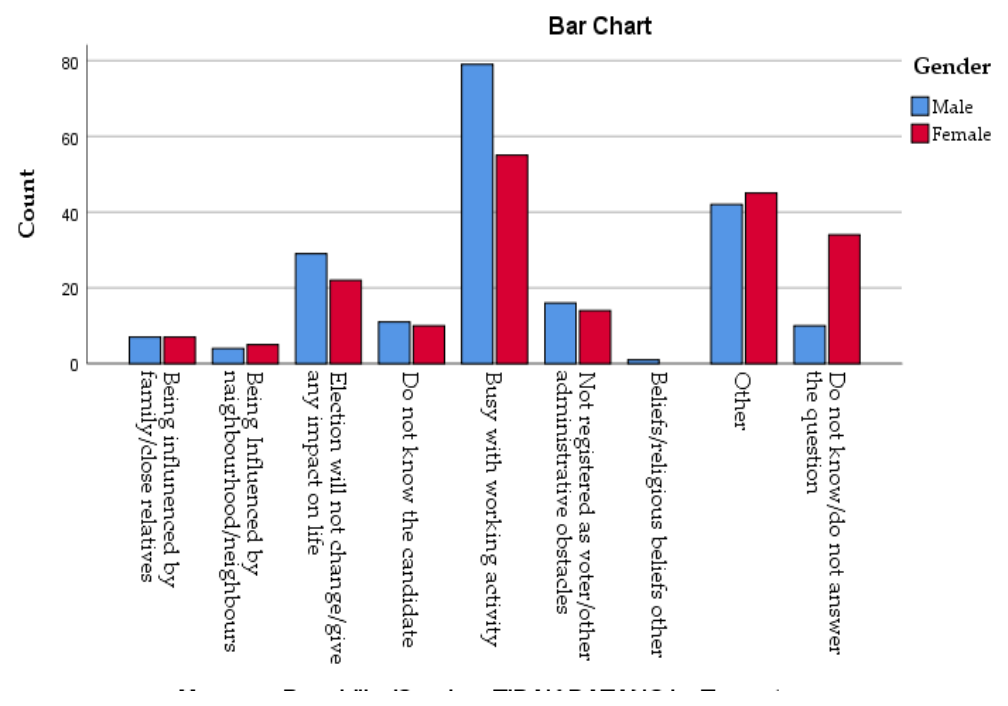

Source: research result, cross tabulation of reasons for abstention and gender 
that was possibly related to the weak gender issue. Indications of it can be seen from NGO activists who actively present women's issues to candidates in exchange for support as stated by women activists in Medan:

"Some NGOs in Medan initiated a political contract with one of the candidates. We offered them a support (note: votes) with the requirement to include the issue of empowerment and the productivity of women's SME ${ }^{16}$ activities as their program in returns. These issues have not been a top priority for both candidates," (interview with Pesada NGO, June 2018).

Therefore, even though skepticism is still apparent, the efforts of women activists were very likely to have an impact in suppressing abstention rates among women. In 2018 the gubernatorial election, abstention among women was only $4-10$ \& below men in each district.

\section{Social Cleavage and Silent Apathy in Ethnicity}

Ethnicity was important issue during the North Sumatra gubernatorial election in 2018. Several clear indications can be seen, among others, from the combination of candidate pairs that strongly reflect aspects of ethnicity and the way these candidate pairs made political negotiations with ethnic-based political forces. The second candidate pair (Djarot Syaiful Hidayat and Sihar Sitorus) seemed to target Javanese-descendant voters who quantitatively made up about $32 \%$ of the total population of Medan. They showed their efforts by exposing Hidayat's profile as Javanese who collaborated with Sitorus's background as Batak. As mentioned, if Javanese-descendant voters were important quantitatively, the Bataks, as North Sumatran natives, were important politically. They were considered able to control important

\footnotetext{
$\overline{{ }^{16} \text { Small and Middle enterprises }}$
}

political forces in Medan and North Sumatra despite their moderate percentage of the total population ${ }^{17}$.

The image of ethnic characteristics did not strongly appear in the candidate pair Edy Rahmayadi and Musa Rajekshah. Coming from outside the majority ethnic groups they wrapped their image as figures who had strong connectivity with Medan. However, they were clearly trying to win the support of Pujakesuma, the biggest Javanese community organization in Medan and North Sumatra. Several factions of this organization had previously supported the second candidate pair (Djarot Syaiful Hidayat and Sihar Sitorus) but Rahmayadi and Rajekshah finally won their affiliation. It was shown from campaign symbols that appear clearly in the public, such as campaign advertisements screened on campaign cars and intense communication between the organization's officials and the Rahmayadi-Rajekshah winning team ${ }^{18}$.

However, ethnic cleavage even showed a paradox when many Javanese voters were not present at the polling stations, thus considered as being abstained. Their number was indicated to be the highest among others (see Figure 2). Affiliation of the largest and influential organization in Javanese society and exposure of candidate profiles that emphasized Javanese ethnicity were not able to attract voters' interest in election. The Javanese abstained voters even indicated silent apathy by stating that economic activity was their main reason for not voting in the election (more than 40 respondents). They also indicated hiding their true answers by choosing the "Others" option (about 25 respondents) and "Did not know / did not answer the question" (around 15 respondents).

\footnotetext{
${ }^{17}$ https://www.merdeka.com/peristiwa/jangan-salahwarga-medan-tak-selalu-identik-dengan-orang-batak. html

${ }^{18}$ As explained by Chairman Pujakesuma through telephone interview, also information from Walid, Spokesperson for the Rahmayadi-Rajekshah Winning Team, June 2018
} 


\section{Figure 2.}

\section{Crosstab on Ethnic and Reasons for Abstention}

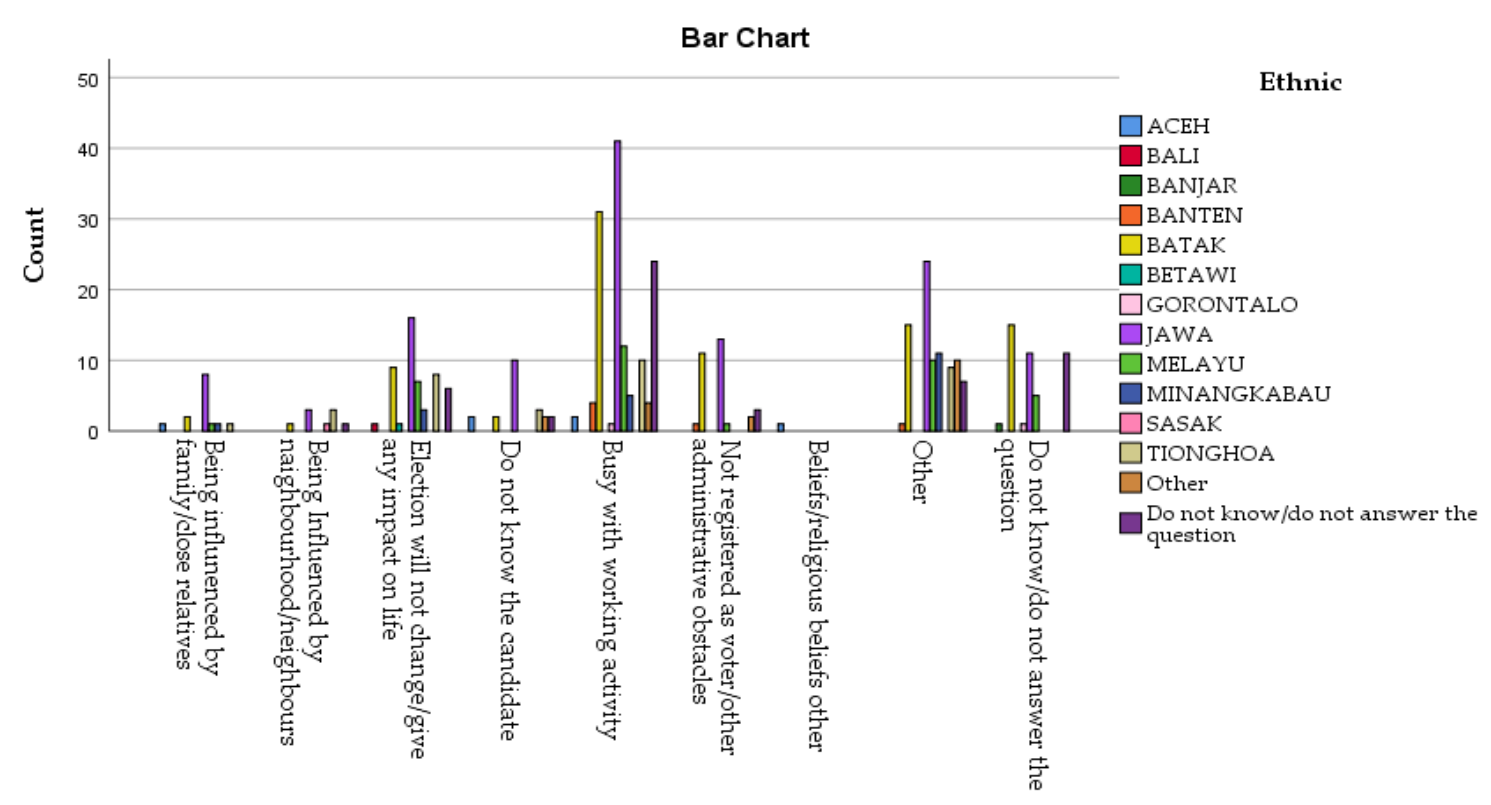

Source: Research result, cross tabulation of reasons for abstention and ethnic

The voters from this dominant ethnic group also stated that the election will not give any change to their lives (around 18 respondents).

Secondly, this research failed to capture the reasons of Chinese voters not to come to the polling stations. The number of abstained voters from this Chinese descendant cluster was indicated significant but researchers failed to get their willingness to be interviewed for filling out the questionnaires ${ }^{19}$. This community group has a sizable contribution to Medan's economy but was considered as not interested in the election ${ }^{20}$. In the midst of difficulties in

\footnotetext{
19 The quantitative data is unavailable. However, the quick identification based on the Chinese names listed in the list of attendees indicated the issue. Similarly, the Focus Group Discussions both with enumerators and stakeholders of election in June 2018 also revealed the indication.

${ }^{20}$ Chinese descendants play an important role in the economy in Medan. Their contribution to the economic and trade sectors is shown among others by the presence of traders who control traditional markets to modern markets. Although, nowadays, their existence is quantitatively competing with traders from various ethnic backgrounds. Their presence in the business sector has been known since the Dutch colonial period
}

identifying their significant contribution to abstention, the general picture in sub-districts which were identified as their settlement area shows a high level of abstention.

Table 6.

\section{Level of Abstention in Sub-districts with Chinese descendant Residents}

\begin{tabular}{lr}
\hline Main Subdistricts & Average of Abstention (Percent) \\
\hline Medan Area & $27-56$ \\
Medan Kota & $44-61$ \\
Medan Maimun & $50-54$ \\
Medan Petisah & $33-60$ \\
Medan Barat & $42-58$ \\
\hline
\end{tabular}

Source: DAA-KWK1 (KPU Medan, 2018)

In addition, in one of the sample polling stations with Chinese-descendant residents (Titi Kuning polling station in Medan Johor sub district), the abstention rate reached $63 \%$.

(around 1930s). https://kumparan.com/potongannostalgia/sekilas-etnis-tionghoa-di-medan. See also Maskur Abdullah in https://www.kompasiana.com/ maskurabdullah/5a6fbcd7bde57533184973f2/benarkahdominasi-bisnis-tionghoa-mulai-bergeser?page=all

${ }^{21}$ https://infopemilu.kpu.go.id/pilkada2018/pemilih/ 
While from Sekip 10 polling station in Medan Petisah Sub district, abstained voters reached $50 \%$. The percentage at that polling station was quite moderate as the abstention in each polling station in this sub district reached $24-70 \%$ or an average of $33-60 \%$ at the sub district level ${ }^{22}$.

In an interview with Thomas Hutoyo (pseudonym), a Chinese descent, voters in his community tend not to vote because they prioritize security and economic business interests $^{23}$. The potential for riots during the election was a concern for many Chinese descent residents. Some of them recalled the miserable social unrest in $1998^{24}$ which targeted the Chinese descent residents and caused economic and social losses ${ }^{25}$. Many of them also mentioned that the election had no impact on their lives. Therefore, the preferred for vacationing or business travels during the polling day. Regarding the issue of impact on life, Hutoyo illustrated that his community generally viewed that their struggles of economic life have been excluded from state's support. In this aspect, skepticism about elections as a political activity that will benefit their lives seemed strongly narrated.

\section{Social Cleavage and Silent Apathy in Religion}

The 2018 North Sumatra Gubernatorial election was a barometer for gubernatorial elections in western Indonesia. The sociological aspect of the election was quite dynamic, including the use of religious issues for election purposes. Utilizing such issues, sympathizers of both candidate pairs expressed

dpt/1/SUMATERA\%20UTARA/KOTA\%20MEDAN/ MEDAN\%20JOHOR/TITI\%20KUNING/3. Also, DAAKWK1-1271111002-TITI KUNING (KPU Medan, 2018)

${ }^{22}$ (DA1-KWK1-127119-MEDAN PETISAH (KPU Medan, 2018)

${ }^{23}$ Interview, June 2018

${ }^{24}$ https://newnaratif.com/journalism/sebuah-isu-politikmengingat-kerusuhan-di-medan-tahun-1998/

${ }^{25}$ As mentioned by the informant. Also see https:// newnaratif.com/journalism/sebuah-isu-politikmengingat-kerusuhan-di-medan-tahun-1998/ their support and tried to influence prospective voters. This was for example by putting up campaign banners on their own initiative and engaged in discourse war on social media. Observations and interviewees also confirmed that Medan in 2018 showed a symptom of religious issues replication as in the Jakarta gubernatorial election in 2017. This situation was seen, among others, with the banners and mobilization of the masses, some were designed by the candidate winning team, but some also showed an element of voluntary. One symptom of voluntary was fundraising through infaq (donations) in mosques as a support for one of the candidates, especially Rahmayadi-Rajekshah.

Furthermore, indication for cleavage in religion aspect was slightly showed by the social divisions in urban areas of Medan, whereas many Muslims were resided in the east coast area while the non-Muslim were resided in the west coast ${ }^{26}$. Although the indication for social cleavage was not as strong as in different area in Indonesia such as in Ambon (see Rahmawati, Prasetyo, \& Marantika, 2019), the political atmosphere in Medan during the gubernatorial election had heated up due to religious issues. The first candidate pair, Rahmayadi-Rajekshah, clearly utilized Islamic religious moments for the campaign and efforts to win votes. They held several major recitals and religious gatherings before and after the Eid al-Fitr. The Islamic conservatives and hardliners seemed to gain the opportunity to show their political strength while being active in those momentums. This also shows the symptoms of religious-based cleavage.

However, data on abstention shows that in the midst of politicization of Islam during the election, voters embraced this religion even showed their unwillingness to be present at the polling stations. Muslims actually contribute

\footnotetext{
${ }^{26}$ Interview with two academics from the North Sumatra University, June 2018.
} 
Figure 3.

Abstained Voters Based on Religious Division

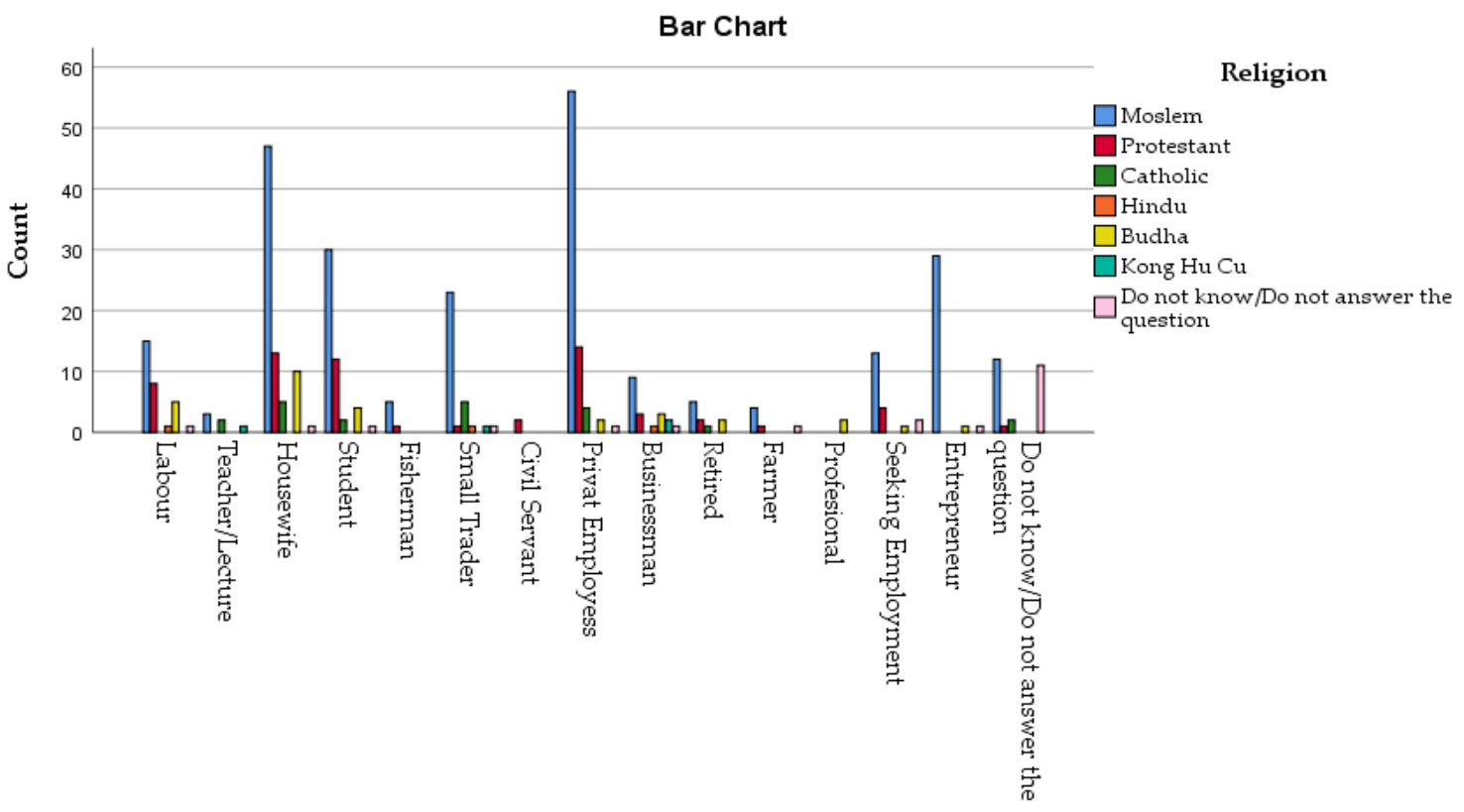

Source: research result, cross tabulation of respondents' occupation and religion

Table 7.

Comparison of Abstention and Population based on Religious Aspects

\begin{tabular}{lrrrrrrr}
\hline & Islam & Christian & Catholic & Hindu & Buddha & Others & $\begin{array}{c}\text { Did not answer the } \\
\text { question }\end{array}$ \\
\hline $\begin{array}{l}\text { Population based on } \\
\begin{array}{l}\text { Religious Aspect* } \\
\text { Abstained Voters }\end{array}\end{array}$ & $65.1 \%$ & $20.7 \%$ & $5.0 \%$ & $1.0 \%$ & $8.1 \%$ & $0.1 \%$ & - \\
\hline
\end{tabular}

Source: * BPS 2018

the largest percentage to abstention (see Figure $3)$. This raises the question whether there is apathy from Muslim voters?

In terms of percentage, the high abstention rate of Muslims was still in balance with the composition of followers of this religion in Medan. However, this did not show a comparable effect to the strong politicization of this religion during the campaign. Meanwhile, a smaller percentage of abstention compared to the composition of religious adherents in Medan was indicated by Christian voters. This indicates their response to religious sentiment during the campaign by increasing voter participation (Table 7).
In this aspect, Islamic voters who abstained indicate apathy towards the politicization of religion during the election. Meanwhile, the less percentage of Christian abstention proves that religious cleavage also had a positive impact in terms of increasing participation (or decreasing abstention). In this case, Christian voters seemed to respond with strong politicization of religion by participating in the election. However, it is possible that Christian voters did not answer the question instead of identifying themselves as Christian voters. If this happens, the possibility of social cleavage based on religion only appeared among Muslims as explained. 


\section{Conclusion}

Departing from social perspective, this study reveals that social cleavages possibly create silent apathy, which is apathy that implicitly influences voters not to come to polling stations. This phenomenon can be seen after bringing up the analysis of both survey results and other findings that were collected through qualitative strategies.

As discussed above, social cleavage in the 2018 gubernatorial election in Medan appeared in the form of ethnic, religious and gender. These three social aspects did not appear merely as social context but rather as cleavages that worked behind the abstention. When parties and interest groups utilized them as a basis for consideration of political actions, groups of people from those three social cleavages even indicated apathy. This ultimately resulted in a paradox.

Gender cleavage, which usually explains the tendency of women to participate in elections compared to men, in this study even shows an opposite tendency, which is hiding more disinterest in election compared to men. They show this tendency by providing vague answers such as "busy with work," "others," and "did not answer the questions. This prompted a small group of women activists to take an initiative to offer voice mobilization in exchange for bringing up a few issues about women in the campaign.

Ethnicity and religion also appeared as strong social cleavages that influenced nonvoting behavior. When candidates use ethnicity and religion as campaign strategies, several groups of voters from the two cleavages even decided not to attend the polling stations. Despite their light excuse for not being at the polling station, they indicated disinterest or apathy towards the election.

Most research relates cleavage to voting propensity, and thus encourages candidates to take advantage of strategic issues favored by targeted cleavage members. Candidates seem to ignore the possibility that a large number of abstained voters are actually members of the same cleavage which they consider capable of contributing a large number of votes. Whereas, these abstained groups do not see elections as an opportunity for change. They do not consider that the flexibility of working time on polling day, which in Indonesia has been designated as a national holiday, is an incentive. Hence, they hide their disinterest to this momentum through activities that are more beneficial to them such as working or doing other activities.

The above phenomenon proves that social cleavage should be considered as an important aspect to explain voters who are not present at the polling stations. The case study not only strengthens the repertoire of literature on non-voting behavior but can also contribute a consideration for participants and voter organizers to formulate a campaign strategy that can better embrace these groups of people with the right to vote.

\section{Acknowledgement}

We would like to express our gratitude to the UGM FISIPOL Grant $(2019 ; 2018)$ and the Research Center for Politics and Government (PolGov) who have supported this research. We would like to extend our sincere gratitude to KPU Medan, JPPR (Voter Education Network for the People), Sigit Pamungkas, the enumerator team, resource persons, election technical officers, academics from USU (North Sumatra University), activists from NGO Pesada, journalists, and respondents. We convey many thanks to Arya Budi and Arga Pribadi Imawan who together with the authors collaborated on a research entitled "Voter Abstention in Regional Election: Case Study of the 2018 Gubernatorial Election in Medan", and have had intense discussions for a research publication plan. 


\section{References}

Abendschon, S., \& Steinmetz, S. (2014). The Gender Gap in Voting Revisited: Women's Party Preferences in a European Context. Social Politics: International Studies in Gender, State \& Society, 21(2), 315-344. https://doi.org/10.1093/sp/jxu009

Achterberg, P. (2006). Class Voting in the New Political Culture. International Sociology, 21(2), 237-261. https://doi. org/10.1177/0268580906061378

Adams, J., Dow, J., \& Merrill, S. (2006). The political consequences of alienation-based and indifference-based voter abstention: Applications to Presidential Elections. Political Behavior, 28(1), 65-86. https://doi. org/10.1007/s11109-005-9002-1

Amin, M. (2014). Relasi Jaringan Organisasi Pemuda dalam Pemilihan Gubernur Sumatera Utara. Jurnal Komunitas, 6(1), 151-158. https://doi.org/10.15294/ komunitas.v6i1.2951

Blais, A., \& Aarts, K. (2006). Electoral Systems and Turnout. Acta Politica, 41(2), 180 196. https://doi.org/10.1057/palgrave. ap.5500148

Budi, A., Widhyharto, D. S., Rahmawati, D., Imawan, A. P., \& Abheseka, N. M. R. (2018). Voters Abstention dalam Pemilihan Kepala Daerah: Studi Kasus Ketidakhadiran Pemilih dalam Pilkada 2018 di Kota Medan. Unpublished Manuscript.

Budi, A., Widhyharto, D. S., Rahmawati, D., Imawan, A. P., \& Abheseka, N. M. R. (2020). Voters Abstention di Indonesia: Ketidakhadiran Pemilih di Kota Medan (Upcoming). Yogyakarta: Penerbit PolGov.

BPS (2018), Kota Medan Dalam Angka, Medan: Badan Pusat Statistik.

Christie, B. E. (2013). Pemukiman Etnis Cina di Medan Pada Akhir Abad Ke-19 Sampai Awal Abad ke 20. Unpublished theris. Universitas Indonesia.
Dalton, R. J. (2010). Ideology, partisanship, and democratic development. In Comparing Democracies: Elections and Voting in the 21st Century. https://doi. org/10.4135/9781446288740.n7

Damanik, E. L. (2018a). Whatsapp dan Pemilih Pemula di Kota Medan : Partisipasi Politik Era Demokrasi Digital pada Pemilihan Gubernur Provinsi Sumatera Utara 2018. The Journal of Society\&Media, 2(2), 81-108. Damanik, E. L. (2018b). Politik Lokal: Dinamika Etnisitas Pada Era Desentralisasi di Sumatera Utara. Medan: Simetri Institute.

Dean, D. G. (1965). Powerlessness and Political Apathy. Social Science, 40(4), 208-213.

DeLuca, T (1995), The Two Faces of Political Apathy. Philadelphia, PA: Temple University Press.

Delwit, P. (2013). The End of Voters in Europe? Electoral Turnout in Europe since WWII. Open Journal of Political Science, 03(01), 4452. https://doi.org/10.4236/ojps.2013.31007

Downs, A. (1957). An Economic Theory of Political Action in a Democracy. Journal of Political Economy, 65(2), 135-150. https:// doi.org/10.1086/257897

Elff, M. (2007). Social Structure and Electoral Behavior in Comparative Perspective: The Decline of Social Cleavages in Western Europe Revisited. Perspectives on Politics, 5(02), 277-294. https://doi.org/10.1017/ S1537592707070788

Evans, J. A. J. (2003). Voters\& Voting: An Introduction. In Sage Publication. https:// doi.org/10.4135/9781446216798

Faraidiany, M. (2016). Politik Identitas Etnis Tionghoa di Kota Medan. Politeia: Jurnal Ilmu Politik, 8(2), 74-82.

Feith, H. (2007). The Decline of Constitutional Democracy in Indonesia. Retrieved from https://books.google.co.id/books?id=VA H0W9uxoqoC\&printsec $=$ frontcover\&hl= id\&source=gbs_ge_summary_r\&cad=0\# $\mathrm{v}=$ onepage\& $\mathrm{q} \& \mathrm{f}=$ false 
Fieldhouse, E., Tranmer, M., \& Russell, A. (2007). Something About Young People or Something About Elections? Electoral Participation of Young People in Europe: Evidence From a Multilevel Analysis of The European Social Survey. European Journal of Political Research, 46(6), 797-822. https://doi.org/10.1111/j.14756765.2007.00713.x

Freixas, J., \& Zwicker, W. S. (2003). Weighted voting, abstention, and multiple levels of approval. Social Choice and Welfare, 21(3), 399-431. https://doi.org/10.1007/s00355003-0212-3

Greene, J. C., Caracelli, V. J., \& Graham, W. F. (1989). Toward a Conceptual Framework for Mixed-Method Evaluation Designs. Educational Evaluation and Policy Analysis, 11(3), 255-274. https://doi. org/10.3102/01623737011003255

Halim, A. (2014). Politik Lokal. Medan: Simetri Institute.

Henn, M., Weinstein, M., \& Forrest, S. (2005). Uninterested Youth? Young People's Attitudes towards Party Politics in Britain. Political Studies, 53(3), 556-578. https://doi. org/10.1111/j.1467-9248.2005.00544.x

Hering, B. B., \& Feith, H. (1963). The Decline of Constitutional Democracy in Indonesia. International Journal. https://doi. org/10.2307/40198726

Hesse-Biber, S. (2010). Qualitative Approaches to Mixed Methods Practice. Qualitative Inquiry, 16(6), 455-468. https://doi. org/10.1177/1077800410364611

Higashikata, T., \& Kawamura, K. (2015). Voting Behavior in Indonesia from 1999 to 2014: Religious Cleavage or Economic Performance? In SSRN Electronic Journal (No. 512). https://doi.org/10.2139/ ssrn.2620455

Inglehart, R., \& Norris, P. (2000). The Developmental Theory of the Gender Gap: Women's and Men's Voting Behavior in Global Perspective. International Political
Science Review, 21(4), 441-463. https://doi. org/10.1177/0192512100214007

Jansen, G., De Graaf, N. D., \& Need, A. (2011). Class Voting, Social Changes and Political Changes in The Netherlands 1971-2006. Electoral Studies, 30(3), 510-524. https:// doi.org/10.1016/j.electstud.2011.02.005

Jelen, T. G., Thomas, S., \& Wilcox, C. (1994). The Gender Gap in Comparative Perspective. European Journal of Political Research, 25(2), 171-186. https://doi. org/10.1111/j.1475-6765.1994.tb00416.x

Kang, W.-T. (2004). Protest Voting and Abstention Under Plurality Rule Elections. Journal of Theoretical Politics, 16(1), 79-102. https://doi.org/10.1177/0951629804038903

Lipset, S. M., \& Rokkan, S. (1967). Cleavage Structures, Party Systems, and Voter Alignments: An Introduction. In Party systems and voter alignments : cross-national perspectives. Free Press.

Martin, A. (2012). Political Participation among the Young in Australia: Testing Dalton's Good Citizen Thesis. Australian Journal of Political Science, 47(2), 211-226. https://doi. org/10.1080/10361146.2012.677003

McClurg, S. D., Wade, M. L., \& Philips, M. V. W. (2012). Gender, Social Networks, and Voting Behavior. In Political Networks Paper Archive (No. 64). Retrieved from http://opensiuc.lib.siu.edu/pn_wp/64/

Mukmin, B. A., \& Damanik, M. R. S. (2018). Demografi Politik Sumatera Utara: Analisis Pilihan Politik Masyarakat Berdasarkan Persebaran Penduduk, Agama dan Etnis Dalam Pemilihan Gubernur Sumatera Utara Tahun 2018 di Kota Medan. Jurnal Geografi, 10(2), 129-144. https://doi.org/10.24114/jg.v10i2.10532

Onwuegbuzie, A. ., \& Collins, K. . (2007). A Typology of Mixed Methods Sampling Designs in Social Science Research. In The Qualitative Report (Vol. 12). Retrieved from https://nsuworks.nova.edu/tqr/ vol12/iss $2 / 9 /$ 
Panggabean, E. S. (2017). Religion, Socio-Economic Status and Voter Behavior: Evidence from a Survey Experiment in Jakarta. Retrieved from http://hdl.handle.net/2105/41631

Pierides, C. (2009). Changing Social Cleavages and the formation of Electoral Behaviour in Greece of the late" Metapolitefsis " (19961997). Athens.

Power, T. J., \& Roberts, J. T. (1995). Compulsory Voting, Invalid Ballots, and Abstention in Brazil. Political Research Quarterly, 48(4), 795-826. https://doi. org/10.1177/106591299504800407

Rahmawati, D., Prasetyo, W., \& Marantika, E. M. (2019). Crossing Primordial Division in Post Conflict Society: Ambon, Peran Jaringan Personal Non-Primordial Kandidat Perempuan dalam Kontestasi Electoral di Pemilu 2019 di Ambon. Unpublished Manuscript.

Reid, A. (2014). The Blood of the People. https:// doi.org/10.2307/j.ctv1qv3jz

Runciman, C. (2016). The 'Ballot and The Brick': Protest, Voting and Non-Voting in Post-Apartheid South Africa. Journal of Contemporary African Studies, 34(4), 419-436. https://doi.org/10.1080/0258900 1.2017.1287347

Ryter, L. (2001). Pemuda Pancasila: The Last Loyalist Free Men of Suharto's Order? In
B. R. O. Anderson (Ed.), Violence and the State in Suharto's Indonesia (pp. 124-155). https://doi.org/10.7591/9781501719042006

Sternheimer, K. (2012). Rethinking Goffman's Front Stage/Back Stage. Retrieved from Everyday Sociology website: https://www. everydaysociologyblog.com/2012/05/ rethinking-goffmans-front-stagebackstage.html

Stoler, A. L. (2005). Kapitalisme dan Konfrontasi di Sabuk Perkebunan Sumatera 1870-1979. Yogyakarta: Karsa.

Thomas, R. M. (1988). The Islamic revival and Indonesian education. Asian Survey, 28(9), 897-915. doi.org/10.2307/2644797

Trihartono, A., \& Patriadi, H. B. (2016). The 2014 Indonesian General Election and Beyond: Melting "Frozen" Cleavages. Asian Journal of Comparative Politics, 1(1), 25-43. https:// doi.org/10.1177/2057891115620699

Windber, M. R. (2020), Political apathy and voting in the United States. Retrieved from Dailyamerican.com, https://www. dailyamerican.com/entertainment/ highschoolhighlights/political-apathyand-voting-in-the-united-states/ article_0de30274-13d4-11eb-89ab97ed3b90b672.html. 